\title{
SH2D1A wt Allele
}

National Cancer Institute

\section{Source}

National Cancer Institute. SH2D1A wt Allele. NCI Thesaurus. Code C75394.

Human SH2D1A wild-type allele is located within Xq25-q26 and is approximately $27 \mathrm{~kb}$ in length. This allele, which encodes $\mathrm{SH} 2$ domain protein $1 \mathrm{~A}$, plays role in activation, proliferation and differentiation of B and T cells, induces production of IFN gamma, and changes the functional profile of subsets of T cells. Mutations in this gene are associated with X-linked lymphoproliferative syndrome 1 (Duncan Disease). 